I hope, also, it may succeed as a sort of living museum, with. out any of the kind of attractions which are not biological ones, and which, indeed, are not scientific in any sense, as common and ribald music, theatricals, acrobatic and jugglery performances, and so forth. Only, no aquarium has ever permanently thriven without these things.

I greatly doubt whether anyone yet possesses the requisite knowledge to be able to rear any marine cunstacean from the egg state to an adult condition, and to feed it in cartivity in such manner as to be able to swil it in the open market at rates below those sold under present circumstances. Yet this is put forward, conspi nously, as one of the aims of the scherne. In Britain are eaten as hurvan food about a dozen species of crabs, lobsters, prawns, and shrimps, and most of these bave been occasionally bred in aquaria as far as the Zoea state, when they are free swimmers, and they then generally die. Rarely, some few have been brought up to a higher stage, but I know of no instance, durin; twenty-five years of experience, where any marine crustacean of any kind has been reared to an adult connition in an aquarium. And if such a thing could he done, $I$ believe that to feed them in any state of captivity, with animal food, which they require in great ahundance and variety, and which must be purchaced, would be very expensive, indeed, far too costly I think, to be practically and commercially remunerative.

I am glad to see that in last week's NATURE, vol. xvii, p. I33, it is stated that that excellently-tasted little frech-water lobster, Astacus, has been bred artificially by a Piscicultural Institution at Schwerin. If so, why should it not be similarly bred in Britain, where it is much stldomer eaten than in France and Germany. In Berlin, Hamburg, and Dresden, I have often purchased it at sixpence a dozen, while in Paris I have given as much as sixpence each for it. Ir. is a piry, however, that the Schwerin account is not more full and explicit. It is stated that in the spring of 1876,700 Astacus in erg, were placed in two round ponds, each of six feet dirmeter. Holes were made in these, and recently, on draining the ponds, only three or four adult crayfish were found straying about the ponds, the rest each being in a separate bole, and a large number of young ones were found, as big as bees, and very lively. What size were the crayfish at birth, and if very small, and swimming, how were they prevented from escaping from the ponds? Information is wanted as to the shape, length, breadth, direction as to angle, and distance apart of these holes, and their position in the ponds, whether in the sides or base, or both. If nearly 700 animals occupied as many holes, where were the young ones? How many young were there? If each female kad only as few as 100 eggs hatched out, then 70,700 must have been the population of these two little pools. When, and in what manner, were the males introduced? We require also to be told of the material of which the ponds were constructed, and if the sides were upright, and the bottoms flat, or if rounded or basin-shaped. If water ran in and out, how much in a named time, of what quality, as to foreign substances it contained in solution and suspension, and what was its temperature at various periods of the year? In what direction and in what amount was light admitted? How much vegetation, and of what kinds, grew in the ponds? What kinds of animal food was given them, and how much and often, and was it cooked or raw ? Carrots appear an odd food for crayfish. I.et all these things and more, be carefully ascertained, to see if they can be applied to the culture of Homarus, the near marine relative of Astacus, before much money is spent.

It would be an excellent thing for students to have a place to study at, such as is proposed to be provided for them at Jersey, and similar to the zoological station and aquarium at Naples, in the arrangement of which I had much to do. But would students be content to go only so far as Jersey? Is not the access too easy, and too cheap, as it is not easy or cheap to go so far as Naples, and to have the name of so going? I have often thought it odd, and evincing not at all a really -zealous spirit in my own direction on the part of my fellow-naturalists, that such a thing should be, that though the Crystal Palace Aquarium has existed for seven years within less than one hour's railway ride from London, and though it contains a constantly advertised collection of living marine animals exceeded in variety and interest by none in Britain, or even Europe, yet no scientific man, except the late Edward Newman, has ever applied for permission to carry on any course of inquiry here on any subject, continuously or occasionally, connected with the habits of living creatures, in the spirit of say, Gilbert. White of Selborne. Yet we offer all such advantages as table-space, good light, and the use of any animals in our tanks not having a considerable money value-lest injury be done to such specimens-absolutely free of all charges. At this moment we possess many Italian aninals in our collection, as fishes, crustaceans, mollusks, z.oophytes, $\delta c$. which can be seen alive nowhere else, save on the shores of the Mediterranean, and yet no professed zoologist known to me ever comes to see them, or takes the smallest interest in them. They are therefore beheld only by the general public, who only look at them for their mere pretiness, or for what untrained observers are complacently pleased to term "ugliness" No student ever asks us for more than any dead animals we may chance to have, and which we give away gratis, and these apparently afford far more pleasure than the sight of living specimens. It is not at all uncommon to meet with biolocists who openly and avowedly proclaim their coutempt for collections of living animals in aquaria, which they regard as being "well enongl for women and children," but for men they say there is nothing like se-ing such animals in rows of glass jars of alcohol on the shelves of a museum. My last contribution of any length to NATURE was made so long ago as October 12, I 871 , when I gave a description of the Crystal Palace Aquarium, then only just opened. Since then we have had no cause to complain of the appreciation of the world of sightseers. But as regards the indifference of the scientific world, that has been and is so great that the place miyht never have existed. William Yarrell, the British ichthyologist of the generaiion just passed away, used to tell me how glad he would be to see a live John Dory (Zeus faber), and how much he would give to behold one swimming. But here, at Sydenham, this fish can he seen alive and in perfect lealth for months together, in crystalline sea-water. Yet no Varrell ever comes to see them. Are there no Yarrells, and Whites, and Watertons, and Newmans now? or has their very spirit passed away into the region of apathy where the affectation of caring for nothing, and of being never moved to zeal in anything, in this cbservation of live animals, seems to be regarded as a very high accomplisbment?

Crystal Palace Aquarium, December I5

W. A. LLOYY

\section{The "Challenger" Estimates of the Volume of the Gulf Stream}

In the interesting "Voyage of the Challenger," just published, Sir Wyville Thomson states (vol. i. p. 37r) "thal the Gulf Stream in its restricted sense was, early in $M$ Iay, $x 873$, at the point where we crossed it and made our observations, about sixty miles in width, Ioo fathoms deep, and its rate three knots an hour." I was much surprised at reading this, as the Admiralty Report on Ocean Soundings, No. 7, p. I2, estimates it at the same point as " 100 fathoms deep, and running at the rate of three miles an hour for a width of fifteen miles, discharging four and a half cubic miles of heated water per hour."

As no reference is made by Sir Wyville Thomson to the extraordinary discrepancy in these two estimates of the same thing at the same time-one being four times the volume of the otherand as he says he makes the statement "thus guardedly" I think, in the interest of scientific accuracy, an explanation is required.

\section{Liverpool, December 8}

T, Mellard Reade

\section{The Fossil Peronospora as a Primordial Plant}

THE concluding sentence of your notıce (vol, xvii. p. 128) of my observations on a fossil fungus is: so important, that I shall be glad of a word of reply. You say, "But should not this primordial plant have led a non-parasitic life? for if parasitical, then this fact points to some pre-existing plant."

Although the specimen I. have figured is shown as growing within the decayed tissues of a Lepidodendron, yet it does not follow that the same fungus could not perfect itself on humus alone. Recent species of Peronospora show a tendency to grow upon the ground, as several species, including the fungus of the potato disease, will grow and proiluce fruit on the naked earth. A truly terrestrial species is found in the allied Botrytis terrestris, Persoon, and many of the Mucedines grow freely in cellars, on damp walls, or in any moist place.

I5, Mildmay Grove, N.
Worthington G. Smith 